\title{
Differentiation of mosquito-pathogenic strains of Bacillus sphaericus from non-toxic varieties by ribosomal RNA gene restriction patterns
}

\author{
Marilena Aquino de Muro, Wilfrid J. Mitchell and Fergus G. Priest * \\ Department of Biological Sciences, Heriot-Watt University, Riccarton, Edinburgh EH14 4AS, UK
}

(Received 15 October 1991; revised 5 January 1992; accepted 28 February 1992)

\begin{abstract}
DNA from 17 strains of Bacillus sphaericus, including representatives of all the established DNA homology groups, was cleaved with EcoRI or HindIII and fragments were separated by agarose gel electrophoresis. Southern blots of this DNA were hybridized to a radioactively labelled DNA probe prepared from the cloned 16S rrnB ribosomal RNA operon of Escherichia coli. Banding patterns of the chromosomal DNA digests and the autoradiograms were specific to DNA homology groups I (B. sphaericus sensu stricto), IIA (mosquito-pathogenic strains), IIB (B. fusiformis) and V, but groups III and IV were not clearly distinguished. This suggests that the mosquito-pathogenic strains represent a separate subspecies.
\end{abstract}

\section{Introduction}

Some strains within the species Bacillus sphaericus are toxic towards mosquito larvae and can be used to control these important vectors of human and animal disease. Larval death results from ingestion of a parasporal crystal which is comprised of two proteins, of 51.4 and $41.9 \mathrm{kDa}$, which are transcribed from adjacent genes (Hindley \& Berry, 1987; Baumann et al., 1988). Both proteins are required for toxicity although the mechanism of action is not known (Baumann et al., 1991).

The basis of $B$. sphaericus classification was established by Krych et al. (1980), who allocated 50 of 62 strains to five DNA homology groups. These groups have since been validated by numerical classification of phenotypic features (Alexander \& Priest, 1990) and enzyme electrophoretic patterns (Singer, 1988). It would seem that these groups represent species, although formal descriptions have not been published. DNA homology group II has been divided into two subgroups: IIA and IIB. All mosquito pathogens (with one possible exception: Guerineau et al., 1991) have been allocated to subgroup IIA (Krych et al., 1980). In two studies, strains within subgroup IIA showed mean DNA sequence homologies of $83 \%$ (Krych et al., 1980) and $71 \%$

\footnotetext{
* Author for correspondence. Tel. (031) 4495111 ext. 4693; fax (031) 451 3009; e-mail bbsfgp @uk.ac.hw.clust.

Abbreviation: DIG, digoxigenin.
}

(Guerineau et al., 1991) while inter-subgroup sequence homologies were $61 \%$ and $63 \%$ respectively. Although this is strong evidence for separating these taxa, the inter-group sequence homology values are higher than is usual for separate species within the genus Bacillus (Priest, 1981) and it is not clear if they should be united or separated. Moreover, with the exception of pathogenicity, there are no definitive phenotypic characters that distinguish these taxa (Alexander \& Priest, 1990). The status of these subgroups is therefore unclear.

In this study we have compared insect-pathogenic strains of subgroup IIA with non-toxic strains of subgroup IIB and various other strains using rRNA gene restriction patterns (Grimont \& Grimont, 1986).

\section{Methods}

Strains and growth conditions. The $B$. sphaericus strains used are described in Table 1. All strains were grown on nutrient agar or in nutrient broth at $30^{\circ} \mathrm{C}$. The Escherichia coli strains used for plasmid preparation were grown in L-broth or on L-agar at $37^{\circ} \mathrm{C}$.

Plasmid preparation and labelling of probes. Plasmid pBSE-18 is pUC12 containing a $3.5 \mathrm{~kb}$ fragment from $B$. sphaericus BSE-18 (Guerineau et al., 1991). The DNA fragment encodes genes for the 41.9 and $51.4 \mathrm{kDa}$ toxin genes (see Fig. $2 c$ ) and is identical in sequence to the $3.5 \mathrm{~kb}$ fragment from strain 2362 (Baumann et al., 1991; C. R. Berry, personal communication). E. coli JM83 containing pBSE-18 and E. coli JA221 containing pKK 3535 (Brosius et al., 1981) were grown in $500 \mathrm{ml}$ batches of L-broth to the mid-exponential phase $\left(\mathrm{OD}_{600} 0 \cdot 6\right)$ and the plasmids amplified in the presence of chloramphenicol $(170 \mu \mathrm{g}$ $\mathrm{ml}^{-1}$ ) overnight. Cultures were harvested and plasmids prepared by the 
A B

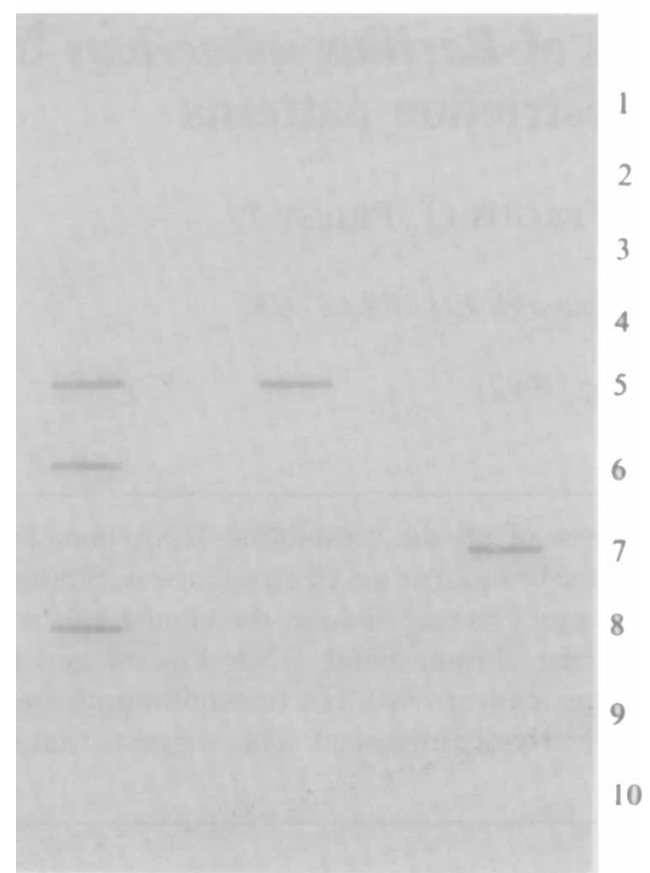

Fig. 1. Slot-blot hybridization of B. sphaericus chromosomal DNA with the toxin gene probe. Chromosomal DNA from $B$. sphaericus strains 2362, BSE-18, 2297, 1593 and JL-60 is shown at positions A5, B5, A6, C7 and A8 respectively. Strain SSII-1 (position B1), and the other strains listed in Table 1, did not hybridize with the toxin gene probe.

SDS lysis procedure (Maniatis et al., 1982) and purified by caesium chloride/ethidium bromide density-gradient centrifugation. Plasmid pKK 3535 was cut with PstI and $X b a I$ and the DNA electrophoresed in $0.8 \%(\mathrm{w} / \mathrm{v})$ low-melting-temperature agarose at $12 \mathrm{~V}$ for $16 \mathrm{~h}$. The $2.9 \mathrm{~kb}$ fragment from pK K 3535 containing the 16S RNA gene from $E$. coli and some surrounding DNA was excised, dissolved in water $(3 \times$ volume), boiled for $7 \mathrm{~min}$ and labelled directly using random oligonucleotide primers (Feinberg \& Vogelstein, 1983, 1984). The pKK 3535 probe was labelled with $\left[\alpha^{-32} \mathrm{P}\right] \mathrm{dCTP}(370 \mathrm{MBq} \mathrm{m})^{-1}$; Amersham); the typical probe activities were 107 c.p.m. $\left(\mu \mathrm{g}\right.$ DNA) ${ }^{-1}$. Plasmid pBSE-18 was used intact after random primed labelling with digoxigenin (DIG)-dUTP (BCL).

DNA extraction, digestion and separation of fragments. Chromosomal DNA was isolated from late-exponential-phase cultures as described previously (Alexander \& Priest, 1989) and 5-10 $\mu \mathrm{g}$ was digested with EcoRI or HindIII (4 units per $\mu \mathrm{g}$ DNA) for $4 \mathrm{~h}$ at $37^{\circ} \mathrm{C}$ in the buffer recommended by the manufacturer (NBL, Cramlington, Northumberland). Digests were electrophoresed at $12 \mathrm{~V}$ for $16 \mathrm{~h}$ in horizontal $0.8 \%$ $(\mathrm{w} / \mathrm{v})$ agarose gels using Tris/acetate buffer (pH 8) (Maniatis et al., 1982). HindIII-generated fragments of $\lambda$ DNA were used as size markers. After electrophoresis, the gels were stained in ethidium bromide $\left(5 \mu \mathrm{g} \mathrm{ml}^{-1}\right)$ and photographed.

Southern blot hybridization to $16 S \mathrm{r} R \mathrm{NA}$ probe. Electrophoresed DNA was denatured and transferred to nitrocellulose membranes by standard procedures (Maniatis et al., 1982). DNA was hybridized to the pKK 3535 probe $\left(2.9 \mathrm{~kb}\right.$ fragment) at $42{ }^{\circ} \mathrm{C}$ for $18 \mathrm{~h}$ in $40 \%(\mathrm{v} / \mathrm{v})$ formamide. Autoradiograms on X-Omat film were exposed with intensifying screens at $-70^{\circ} \mathrm{C}$ for up to $24 \mathrm{~h}$.
Table 1. Characteristics of B. sphaericus strains

\begin{tabular}{|c|c|c|c|c|c|}
\hline \multirow[b]{2}{*}{ Strain* } & \multirow{2}{*}{$\begin{array}{l}\text { DNA } \\
\text { group } \dagger\end{array}$} & \multicolumn{2}{|c|}{$\begin{array}{l}\text { rRNA } \\
\text { (R) group } \ddagger\end{array}$} & \multirow{2}{*}{$\begin{array}{l}\text { Toxin } \\
\text { gene§ }\end{array}$} & \multirow{2}{*}{$\begin{array}{l}\text { Patho- } \\
\text { genicity }\end{array}$} \\
\hline & & HindIII & EcoRI & & \\
\hline $\begin{array}{l}\text { ATCC } 14577^{* *} \\
\text { BS } 84\end{array}$ & $\begin{array}{c}\text { I } \\
\text { ND }\end{array}$ & $\begin{array}{l}\text { RI } \\
\text { RI }\end{array}$ & $\begin{array}{l}\text { RI } \\
\text { RI }\end{array}$ & $\begin{array}{l}- \\
-\end{array}$ & $\frac{-}{\mathrm{ND}}$ \\
\hline $\begin{array}{l}2362 \\
1593^{* *} \\
\text { SSII-1 } \\
2297 \\
\text { BSE-18 } \\
\text { JL-60 }\end{array}$ & $\begin{array}{l}\text { IIA } \\
\text { IIA } \\
\text { IIA } \\
\text { IIA } \\
\text { IIB } \\
\text { ND }\end{array}$ & $\begin{array}{c}\text { RIIA } \\
\text { RIIA } \\
\text { (RIIA) } \\
\text { RIIA } \\
\text { RIIA } \\
\text { ND }\end{array}$ & $\begin{array}{c}\text { RIIA } \\
\text { RIIA } \\
\text { RIIA } \\
\text { RIIA } \\
\text { (RIIA) } \\
\text { ND }\end{array}$ & $\begin{array}{l}+ \\
+ \\
- \\
+ \\
+ \\
+\end{array}$ & $\begin{array}{l}\text { High } \\
\text { High } \\
\text { Low } \\
\text { High } \\
\text { High } \\
\text { High }\end{array}$ \\
\hline $\begin{array}{l}\text { ATCC } 7055^{* *} \\
\text { DSM } 493\end{array}$ & $\begin{array}{l}\text { IIB } \\
\text { IIB }\end{array}$ & $\begin{array}{l}\text { RIIB } \\
\text { (RIIB) }\end{array}$ & $\begin{array}{l}\text { RIIB } \\
\text { (RIIB) }\end{array}$ & - & $\begin{array}{l}\text { ND } \\
\text { ND }\end{array}$ \\
\hline $\begin{array}{l}\text { NRS } 592^{* *} \\
\text { P1 } \\
\text { BS } 112\end{array}$ & $\begin{array}{l}\text { III } \\
\text { III } \\
\text { ND }\end{array}$ & $\begin{array}{l}\text { RIII } \\
\text { (RIII) } \\
\text { (RIII) }\end{array}$ & $\begin{array}{l}\text { RIII } \\
\text { RIII } \\
\text { RIII }\end{array}$ & $\begin{array}{l}- \\
- \\
-\end{array}$ & $\begin{array}{l}\text { ND } \\
\text { ND } \\
-\end{array}$ \\
\hline $\begin{array}{l}\text { NRS } 400^{* *} \\
\text { NRS } 1693 \\
\text { ATCC } 13805\end{array}$ & $\begin{array}{l}\text { IV } \\
\text { IV } \\
\text { IV }\end{array}$ & $\begin{array}{l}\text { RIV } \\
\text { (RIII) } \\
\text { (RIII) }\end{array}$ & $\begin{array}{l}\text { (RIII) } \\
\text { RIII } \\
\text { (RIII) }\end{array}$ & $\begin{array}{l}- \\
- \\
-\end{array}$ & $\begin{array}{l}\text { ND } \\
\text { ND } \\
\text { ND }\end{array}$ \\
\hline $\begin{array}{l}\text { NRS } 1198^{* *} \\
\text { NRS } 1199\end{array}$ & $\begin{array}{l}\mathrm{V} \\
\mathrm{V}\end{array}$ & $\begin{array}{l}\text { RV } \\
\text { RV }\end{array}$ & $\begin{array}{l}\text { RV } \\
\text { RV }\end{array}$ & $\begin{array}{l}- \\
-\end{array}$ & $\begin{array}{l}\text { ND } \\
\text { ND }\end{array}$ \\
\hline
\end{tabular}

ND, Not determined.

* All strains have been fully described previously (Alexander \& Priest 1990) with the exception of JL-60, provided by A. A. Yousten, Virginia, USA.

** Denotes reference strains.

$\dagger$ DNA groups are based on results of Krych et al. (1980).

$\ddagger R$ groups in parentheses indicate slight deviation from the reference pattern.

$\S$ Toxin genes demonstrated by slot-blot hybridization (this paper) and also reported by others (see Baumann et al., 1991 for a review).

$\|$ Pathogenicity reported by Theiry \& de Barjac (1989) and A. A. Yousten (personal communication).

Slot-blot hybridization for detection of toxin gene. Slot-blots were prepared with approximately $1 \mu \mathrm{g}$ of chromosomal DNA immobilized on nitrocellulose membranes using the Minifold II system (Schleicher \& Schuell). Filters were probed with the DIG-labelled pBSE-18 DNA at $42{ }^{\circ} \mathrm{C}$ for $16 \mathrm{~h}$ in $40 \%(\mathrm{v} / \mathrm{v})$ formamide. Exactly the same results were obtained using either the total plasmid or the excised $3.5 \mathrm{~kb}$ HindIII fragment as probe. Filters were washed and the bound DNA detected using the BCL detection kit, which is based on an alkalinephosphatase-conjugated antibody reaction.

Plasmid preparation from B. sphaericus. B. sphaericus strains were grown in $100 \mathrm{ml}$ batches of L-broth to the late exponential phase $(12 \mathrm{~h}$ at $30^{\circ} \mathrm{C}$ ). Cultures were centrifuged for $10 \mathrm{~min}$ at 6000 r.p.m., and the pellet was resuspended in $10 \mathrm{ml}$ TEN buffer $(10 \mathrm{~mm} \mathrm{Tris} / \mathrm{HCl} \mathrm{pH} 7 \cdot 6$, $1 \mathrm{mM}-\mathrm{EDTA}, 10 \mathrm{~mm}-\mathrm{NaCl}$ ). After centrifugation, $20-30 \mathrm{mg}$ of cells were resuspended in $1 \mathrm{ml}$ SET buffer $(20 \%, \mathrm{w} / \mathrm{v}$, sucrose, $50 \mathrm{~mm}$-Tris pH 7.6, $50 \mathrm{~mm}$-EDTA) by thoroughly vortexing for $1 \mathrm{~min}$. The plasmids were prepared as described by Rodriguez \& Tait (1983) for $B$. subtilis. Plasmids were electrophoresed at $12 \mathrm{~V}$ for $16 \mathrm{~h}$ in horizontal $0.8 \%(w / v)$ agarose gels using Tris/acetate buffer ( $\mathrm{pH} 8)$. The respective chromosomal DNA of each strain used for plasmid preparation was digested with $\mathrm{HindIII}$ for $4 \mathrm{~h}$ at $37^{\circ} \mathrm{C}$ and electrophoresed in the same gel. The gels were stained in ethidium bromide $(5 \mu \mathrm{g}$ $\mathrm{ml}^{-1}$ ) and photographed before Southern blotting and hybridization to the DIG-labelled pBSE-18 probe DNA. 


\section{Results}

\section{Localization of toxin genes}

The cloned toxin genes from B. sphaericus BSE-18 hybridized strongly to total DNA from high-toxicity strains of group IIA in slot-blot hybridizations but not to DNA from any other $B$. sphaericus strain, including the low-toxicity strain SSII-1 (Table 1, Fig. 1). Since it did not hybridize to strain SSII-1 it can be concluded that the $3.5 \mathrm{~kb}$ fragment is specific for the toxin genes and surrounding DNA.
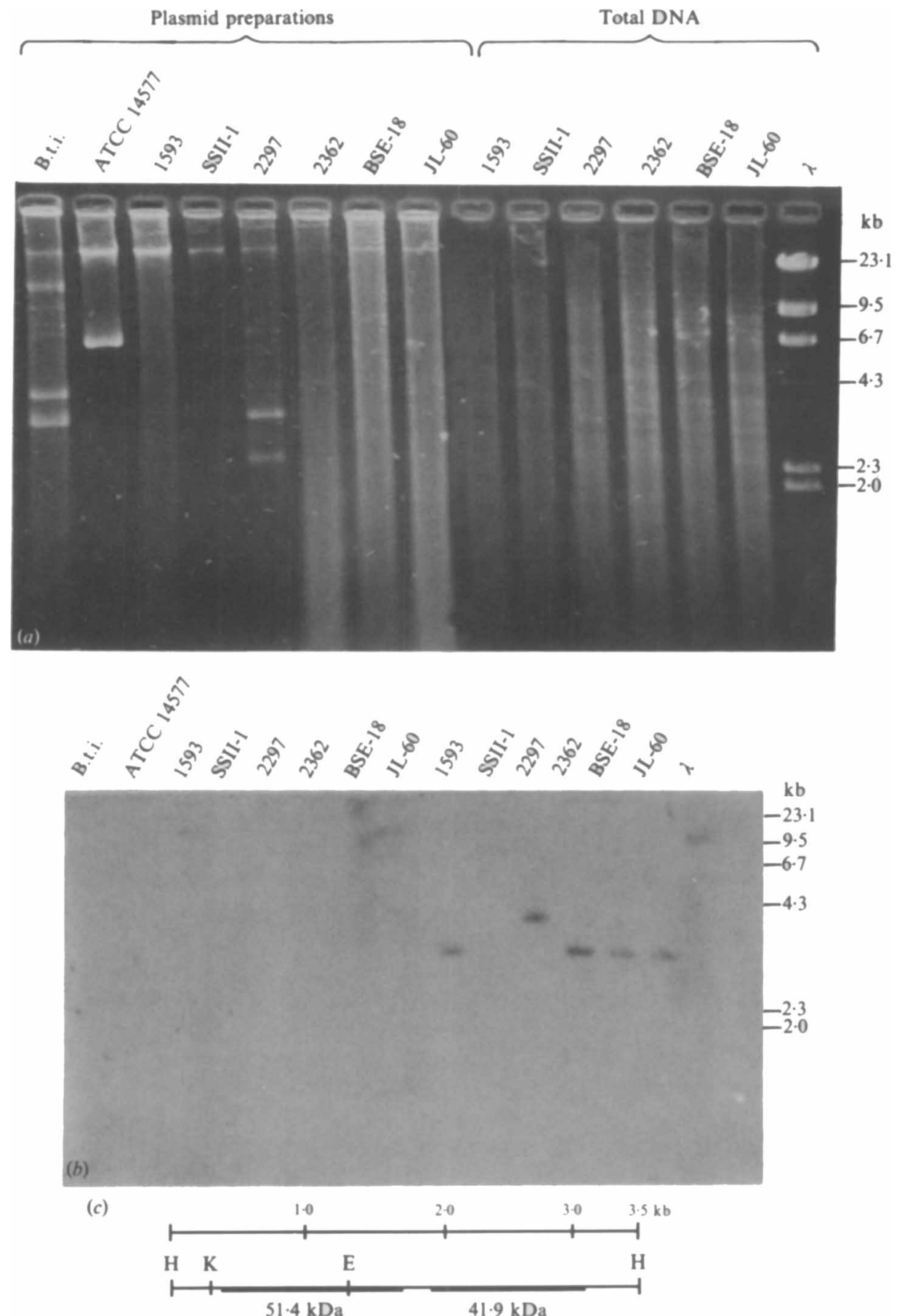

Fig. 2(a). Agarose gel electrophoresis of undigested plasmids and HindIII-digested chromosomal DNA. Lanes 1-8, plasmid DNA from B. thuringiensis var. israelensis (B.t.i.) and from the B. sphaericus strains shown; lanes 9-14, chromosomal DNA from the B. sphaericus strains shown. Fragment sizes are indicated on the right for HindIII-digested fragments of bacteriophage $\lambda$ DNA. (b) Southern blot hybridization of $B$. sphaericus plasmids and chromosomal DNA with DIG-labelled pBSE-18 probe. Fragment sizes are indicated on the right for HindIII-digested fragments of bacteriophage $\lambda$ DNA. (c) Map of the $3.5 \mathrm{~kb}$ HindIII fragment containing the genes for the 51.4 and $41.9 \mathrm{kDa}$ proteins from B. sphaericus strain BSE-18. Abbreviations: E, EcoRI; K, KpnI; H, HindIII. (C. R. Berry, personal communication.) 

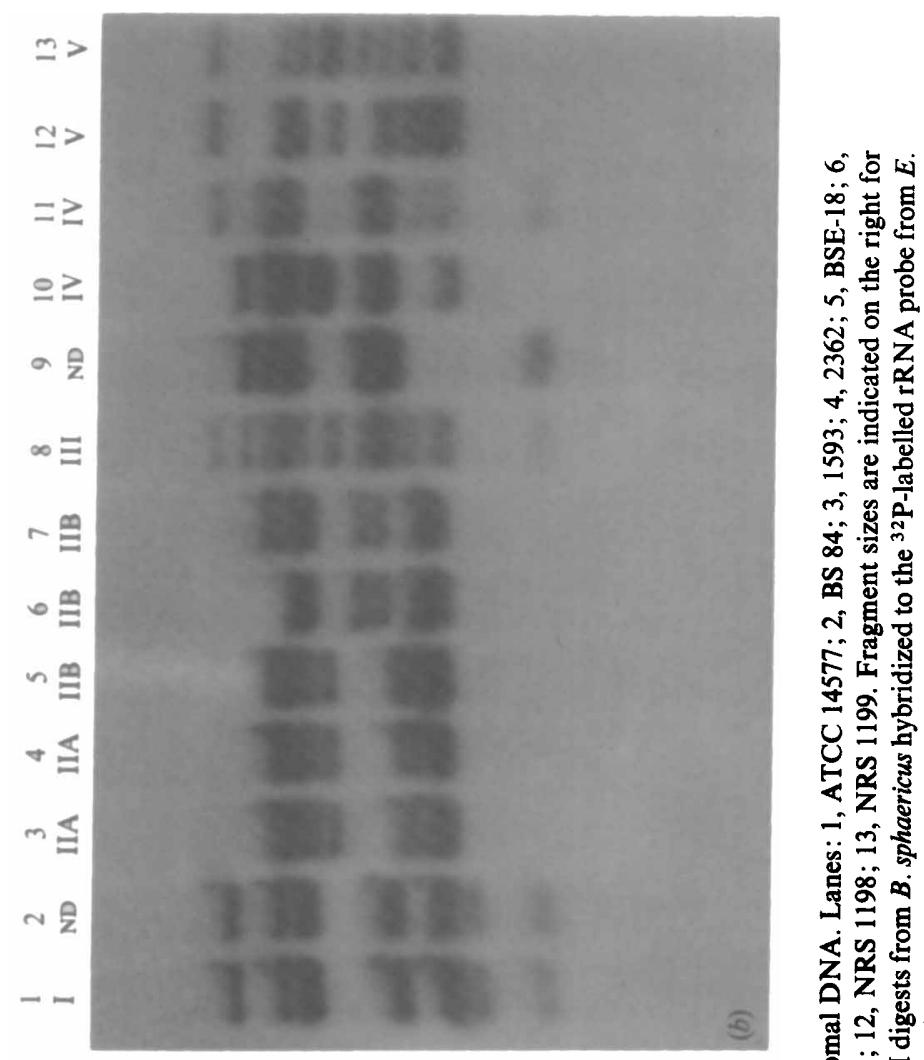

in

递需

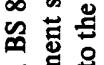

人

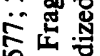

定

을

$<\frac{2}{2}$

$\therefore$.

बै के

ฮㅇ

$<$ 裙

范荌

蛋器.

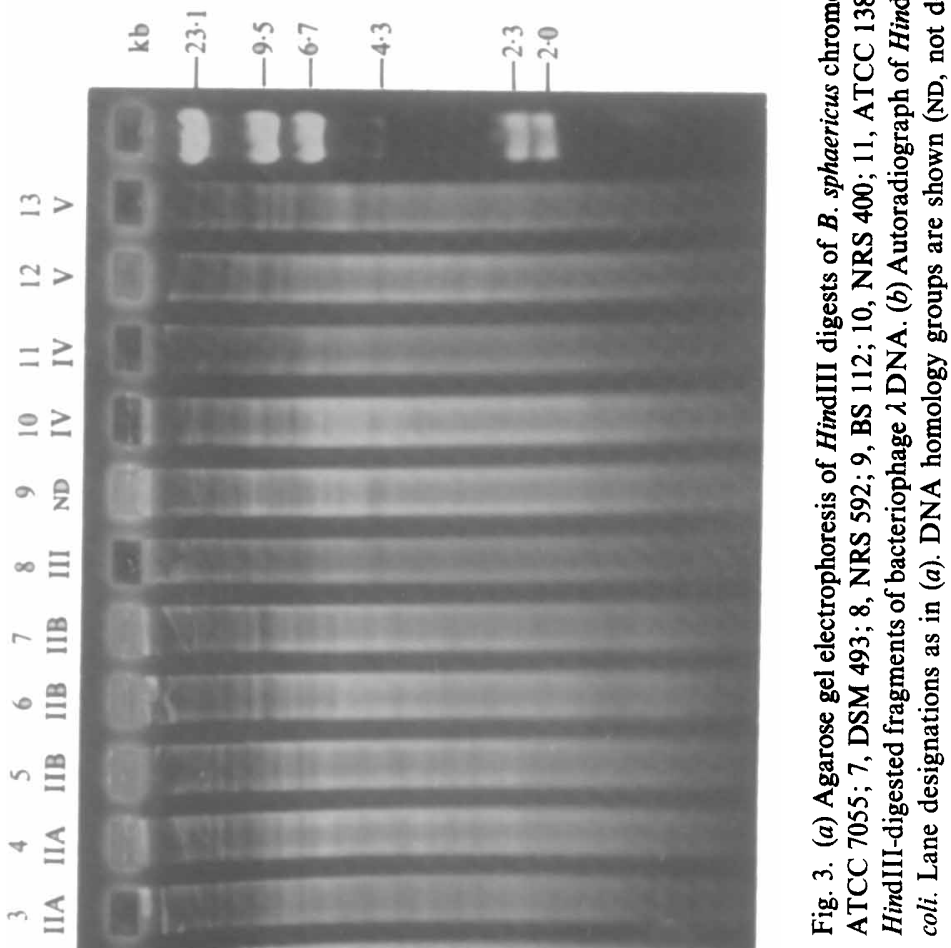




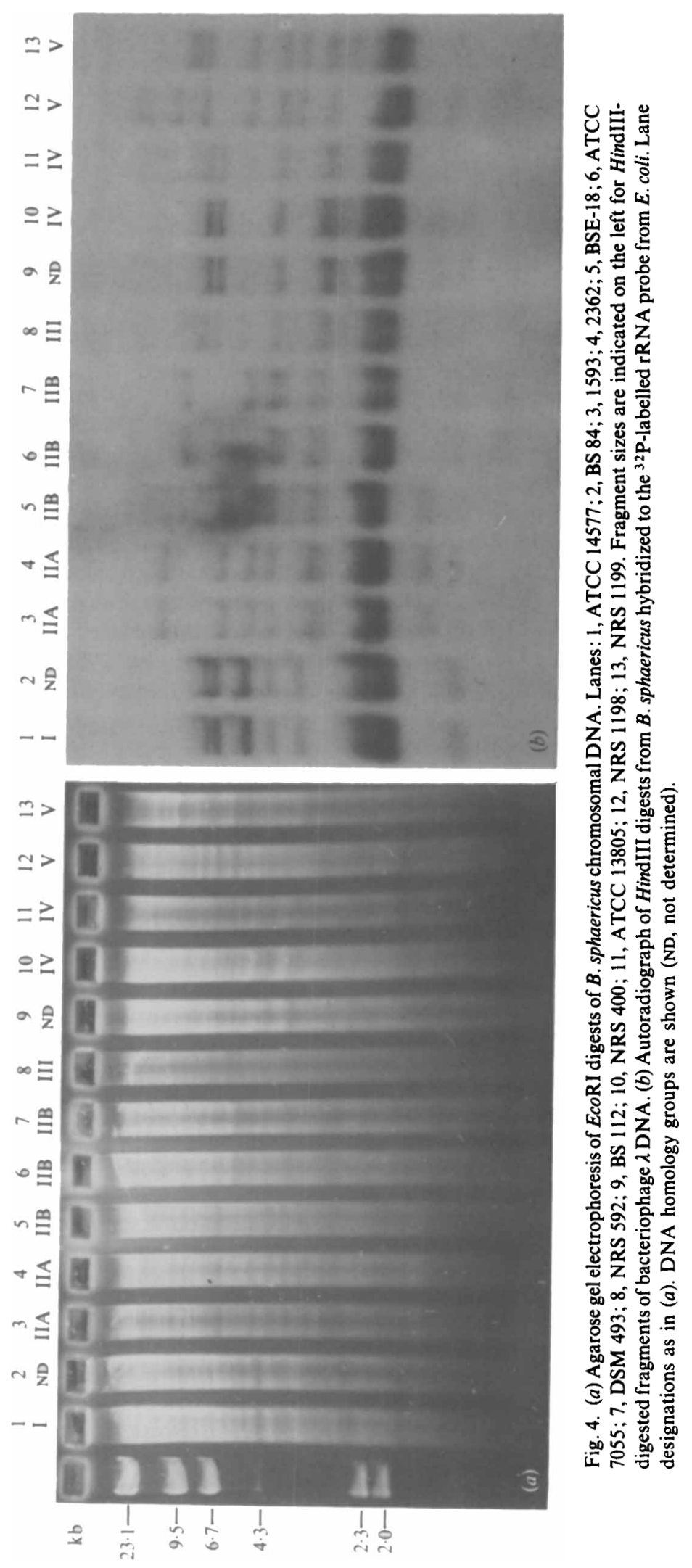


Plasmids were prepared from the hybridizing strains of $B$. sphaericus, and from the type strain and strain SSII1 of $B$. sphaericus, and B. thuringiensis var. israelensis (B.t.i.), as controls. Plasmid DNA was analysed by agarose gel electrophoresis (Fig. 2a). Large plasmids were detected in strains ATCC 14577, 1593, SSII-1, 2297, 2362, BSE-18 and JL-60. Although it is possible that it represents chromosomal DNA, the large plasmid band is well defined and similar-sized plasmids ( $75 \mathrm{MDa}$ ) have been reported in most of these strains by Singer (1988). Additionally, the non-pathogenic type strain (ATCC 14577) and the mosquito pathogen (2297) contained smaller plasmids. B. thuringiensis var. israelensis typically contains six plasmids, of $72,63,10,4.9,4 \cdot 3$ and 3.6 MDa (Himeno et al., 1985), which provides an indication of the sizes of the plasmids in strains ATCC 14577 and 2297. A Southern blot of the gel, which contained HindIII-digested chromosomal DNAs as controls, was hybridized with the cloned toxin genes in pBSE-18. None of the plasmid DNAs hybridized, including the putative high-molecular-mass species (Fig. $2 b$ ). If this had been chromosomal DNA, hybridization would have been expected, and indeed a faint band can be observed in lane 3 (strain 1593) indicating contamination by chromosomal DNA. However, when total DNA prepared from these strains was digested with HindIII, electrophoresed and hybridized distinct bands were revealed at about $4.6 \mathrm{~kb}$ for strain 2297 and $3.5 \mathrm{~kb}$ for the others. This suggests strongly that the toxin genes are located on the chromosome rather than on plasmids in these $B$. sphaericus strains.

\section{$r R N A$ gene restriction patterns of $B$. sphaericus strains}

Chromosomal DNA from $B$. sphaericus strains was digested with HindIII (Fig. $3 a$ ) or EcoR1 (Fig. 4a) and separated by agarose gel electrophoresis. Visual inspection of the gels revealed distinct banding patterns associated with the DNA homology groups. Moreover, the patterns of group IIA and IIB strains were distinguishable. Southern blots of this DNA were hybridized with a ${ }^{32} \mathrm{P}$-labelled DNA fragment representing most of the $16 \mathrm{~S}$ rRNA gene from $E$. coli. Autoradiographs of the hybridized filters revealed distinct banding patterns for each of the DNA homology groups (Figs $3 b$, $4 b$ ). EcoR 1 digests produced patterns of 6 to 11 bands ranging from $1 \mathrm{~kb}$ to $20 \mathrm{~kb}$ while the HindIII digests produced more bands, ranging from $2 \mathrm{~kb}$ to $20 \mathrm{~kb}$. Patterns were designated according to that produced by the reference strain and are listed in Table 1. Of particular relevance is that toxic strains of group IIA produced unique patterns which were different from group IIB strains and strains of $B$. sphaericus sensu stricto. One anomaly to this classification was strain BSE-18 which, although a high-toxicity strain, had previously been assigned to DNA homology group IIB (Guerineau et al., 1991). The results presented in Figs 3 and 4 show that it should be placed in group IIA. On the other hand, strains of DNA homology groups III and IV were not easily distinguished by this method.

\section{Discussion}

The mosquito-pathogenic $B$. sphaericus strains contained large and, for strain 2297 , small plasmids. The distribution and sizes of these plasmids were similar to those reported in previous studies (Singer, 1988) with the exception that a plasmid was detected in strain ATCC 14577. However, unlike the other mosquito pathogen, $B$. thuringiensis var. israelensis, in which the toxin genes reside on the 72 MDa plasmid (Hofte \& Whiteley, 1989), it seems that the toxin genes of $B$. sphaericus are located on the chromosome rather than on the plasmids (Fig. $2 a$, $b$ ). The Southern blots of the plasmids revealed no hybridization but the digests of total DNA showed toxin genes on similar-sized fragments to those described by Baumann et al. (1988), with strain 2297 giving an atypical pattern. This chromosomal location might explain the extreme conservation of $B$. sphaericus toxin genes (Berry et al., 1989) compared to the divergence of $B$. thuringiensis toxin genes into various classes pathogenic for Lepidoptera, Coleoptera and Diptera. A plasmid location would allow transfer of the toxin genes by conjugation into strains of the $B$. thuringiensis $-B$. cereus group followed by recombination with resident genes leading to the development of novel sequences, a situation less likely to occur for chromosomally resident $B$. sphaericus toxin genes.

The different location also has a bearing on the systematics of $B$. sphaericus and $B$. thuringiensis. $B$. thuringiensis strains are essentially strains of $B$. cereus that harbour plasmids bearing crystal protein genes. There is no inherent difference between the two species other than the presence of specific plasmids (Somerville \& Jones, 1972; Gonzalez et al., 1982; Zahner et al., 1989). Mosquito-pathogenic $B$. sphaericus strains, on the other hand, represent a different species from $B$. sphaericus sensu stricto. Although toxin genes of the 51 and $42 \mathrm{kDa}$ class are not invariably present in the pathogens (see Table 1), all strains examined so far contain the 'lowtoxicity' gene (Thanabalu et al., 1991), and the pathogens differ in several other phenotypic characters from $B$. sphaericus sensu stricto (Alexander \& Priest, 1990). Moreover, there is low DNA sequence homology between the two taxa (Krych et al., 1980). These differences are borne out by the variation in chromosomal DNA restriction enzyme digests (Figs $3 a$ and $4 a$ ). Strains of different species of Providencia (Owen et al., 
1988), Helicobacter (Morgan \& Owen, 1990), Campylobacter (Hernandez et al., 1991) and several other Gramnegative species (reviewed by Grimont \& Grimont, 1991) similarly reveal species-specific banding patterns in this technique.

The distinction of the pathogens from B. sphaericus sensu stricto was supported by the rRNA gene patterns, and these also showed that DNA homology groups IIA (pathogens) and IIB (non-pathogens) were different. Indeed, strain BSE-18, previously thought to be a member of group IIB from DNA sequence homology studies (Guerineau et al., 1991), typed unambiguously as a member of group IIA by rRNA patterns (Figs $3 b, 4 b$ ). How does this information relate to the classification of group II strains? It is generally accepted that strains within a species should show greater than $70 \%$ DNA sequence homology with a thermal instability of hybrids $\left(\Delta T_{\mathrm{m}}\right)$ less than $6^{\circ} \mathrm{C}$ (Grimont \& Grimont, 1991). This indicates that strains of groups IIA and IIB, which share about $62 \%$ DNA sequence homology, with a $\Delta T_{m}$ of about $7{ }^{\circ} \mathrm{C}$ (Krych et al., 1980), cannot be allocated to the same species. Different subspecies within a species usually show $\Delta T_{\mathrm{m}}$ values between 2 and $5^{\circ} \mathrm{C}$ whereas strains within a subspecies show $\Delta T_{\mathrm{m}}$ values close to zero (Grimont \& Grimont, 1991). Values for $\Delta T_{\mathrm{m}}$ within groups IIA and IIB are less than $2.5^{\circ} \mathrm{C}$ (Krych et al., 1980), suggesting subspecies status for these taxa. The rRNA gene restriction patterns shown in Figs $3(b)$ and $4(b)$ fully support this classification since patterns for subspecies generated to date such as those for Serratia odorifera biotypes I and II (Grimont \& Grimont, 1991) and Campylobacter jejuni subsp. jejuni and subsp. doylei (Hernandez et al., 1991) have been subspecies-specific. Since group IIB strains have been named $B$. fusiformis (Priest et al., 1988) this would mean that group IIA strains should be allocated to a subspecies of $B$. fusiformis.

The rRNA gene restriction patterns for strains of DNA homology groups III and IV did not provide definitive patterns. This probably reflects the poor classification of these bacteria and perhaps the incorrect allocation of some strains to DNA homology group IV when their rRNA patterns are similar to those of homology group III. Studies of additional strains from these groups by rRNA gene restriction patterns might clarify the systematics of these bacteria.

M. Aquino de Muro is supported by a post-graduate research scholarship from the Brazilian Ministry of Education - CAPES.

\section{References}

Alexander, B. \& PRIest, F. G. (1989). Bacillus glucanolyticus, a new species that degrades a variety of beta-glucans. International Journal of Systematic Bacteriology 39, 112-115.
Alexander, B. \& Priest, F. G. (1990). Numerical classification and identification of Bacillus sphaericus including some strains pathogenic for mosquito larvae. Journal of General Microbiology 136, 367376.

Baumann, L., Broadwell, A. M. \& BaumanN, P. (1988). Sequence analysis of the mosquitocidal toxin genes encoding 51.4- and 41.9kilodalton proteins from Bacillus sphaericus 2362 and 2297. Journal of Bacteriology 170, 2045-2050.

Baumann, P., Clark, M. A., Baumann, L. \& Broadwell, A. M. (1991). Bacillus sphaericus as a mosquito pathogen: properties of the organism and its toxins. Microbiological Reviews 55, 425-436.

BerRY, C., JACKSON-YAP, J. , OEI, C. \& HindLEY, J. (1989). Nucleotide and deduced amino acid sequences of the $51.4 \mathrm{kDa}$ and $41.9 \mathrm{kDa}$ larvicidal toxin genes from Bacillus sphaericus: sequence comparisons between five highly toxic strains. Nucleic Acids Research 17, $7516-7517$.

Brosius, J., Ullrich, A., Raker, M. A., Gray, A., Dull, T. J., Gutell, R. R. \& NolleR, H. F. (1981). Construction and fine mapping of recombinant plasmids containing the $r r n B$ ribosomal RNA operon of Escherichia coli. Plasmid 6, 112-118.

Feinberg, A. P. \& Vogelstein, B. (1983). A technique for radiolabeling DNA restriction endonuclease fragments to high specific activity. Analytical Biochemistry 132, 6-13.

Feinberg, A. P. \& Vogelstein, B. (1984). Addendum. Analytical Biochemistry 137, 266-267.

Gonzalez, J. M., JR, Brown, B. S. \& Carlton, B. C. (1982). Transfer of Bacillus thuringiensis plasmids coding for delta-endotoxin genes among strains of $B$. thuringiensis and $B$. cereus. Proceedings of the National Academy of Sciences of the United States of America 79, 695.1-6955.

Grimont, F. \& Grimont, P. A. D. (1986). Ribosomal ribonucleic acid gene restriction patterns as potential taxonomic tools. Annales de l'Institute Pasteur/Microbiologie 137B, 165-175.

Grimont, F. \& Grimont, P. A. D. (1991). DNA fingerprinting. In Nucleic Acid Techniques in Bacterial Systematics, pp. 249-279. Edited by E. Stackebrandt \& M. Goodfellow. Chichester: John Wiley.

Guerineau, M., Alexander, B. \& Priest, F. G. (1991). Isolation and identification of mosquito pathogenic strains of Bacillus sphaericus. Journal of Incertebrate Pathology 57, 325-333.

Hernandez, J., Owen, R. J., Costas, M. \& Lastovica, A. (1991). DNA-DNA hybridization and analysis of restriction endonuclease and rRNA gene patterns of atypical (catalase weak/negative) Campylobacter jejuni from pediatric blood and faecal cultures. Journal of Applied Bacteriology 70, 71-80.

Himeno, M., IKeda, M., Sen, K., Koyama, N., Komano, T., Yamamoto, H. \& NaKayama, I. (1985). Plasmids and insecticidal activity of delta-endotoxin crystals from Bacillus thuringiensis var. israelensis. Agricultural and Biological Chemistry 49, 573-580.

HINDLEY, J. \& BERRY, C. (1987). Identification, cloning and sequence analysis of the Bacillus sphaericus 159341.9 kilodalton larvicidal toxin gene. Molecular Microbiology 1, 187-194.

HOFTE, H. \& WHITELEY, H. R. (1989). Insecticidal crystal proteins of Bacillus thuringiensis. Microbiological Reviews 53, 242-255.

KRYCH, V. K., Johnson, J. L. \& Yousten, A. A. (1980). Deoxyribonucleic acid homologies among strains of Bacillus sphaericus. International Journal of Systematic Bacteriology 30, 476-484.

Maniatis, T., Fritsch, E. F. \& Sambrook, J. (1982). Molecular Cloning: a Laboratory Manual. Cold Spring Harbor, NY: Cold Spring Harbor Laboratory.

MORGAN, D. D. \& OWEN, R. J. (1990). Use of DNA restriction endonuclease digest and ribosomal RNA gene probe patterns to fingerprint Helicobacter pylori and Helicobacter mustelae isolated from human and animal hosts. Molecular and Cellular Probes 4, 321334.

Owen, R. J., Beck, A., Dayal, P. A. \& Dawson, C. (1988). Detection of genomic variation in Providencia stuartii clinical isolates by analysis of DNA restriction fragment length polymorphisms containing rRNA cistrons. Journal of Clinical Microbiology 26, 21612166.

PrIest, F. G. (1981). DNA homology in the genus Bacillus. In The Aerobic Endospore-forming Bacteria: Classification and Identification, 
pp. 33-57. Edited by R. C. W. Berkeley \& M. Goodfellow. London: Academic Press.

Priest, F. G., Goodfellow, M. \& TodD, C. (1988). A numerical classification of the genus Bacillus. Journal of General Microbiology 134, 1847-1882.

RoDRIgUeZ, R. L. \& TAIT, R. C. (1983). Recombinant DNA Techniques - an Introduction. London: Addison-Wesley.

SINGER, S. (1988). Clonal populations with special reference to Bacillus sphaericus. Advances in Applied Microbiology 33, 47-74.

SOMERVILLE, H. J. \& JONES, M. L. (1972). DNA competition experiments within the Bacillus cereus group of bacilli. Journal of General Microbiology 73, 252-265.
Thanabalu, T., Hindley, J., Jackson-YaP, J. \& Berry, C. (1991). Cloning, sequencing and expression of a gene encoding a 100kilodalton mosquitocidal toxin from Bacillus sphaericus SSII-1. Journal of Bacteriology 173, 2776-2785.

TheIRY, I. \& DE BARJAC, H. (1989). Selection of the most potent Bacillus sphaericus strains based on activity ratios determined on three mosquito species. Applied Microbiology and Biotechnology 31, 577581 .

Zahner, V., Momen, H., Salles, C. A. \& Rabinovitch, L. (1989). A comparative study of enzyme variation Bacillus cereus and Bacillus thuringiensis. Journal of Applied Bacteriology 67, 275-282. 